
\title{
25 Research Soure \\ Identification of sentinel plant species for evaluating phytotoxicity of veterinary antibiotics in mediterranean europe
}

Rosa M. García ( $\nabla$ rosamaria.garcia@inia.es)

INIA: Instituto Nacional de Investigacion y Tecnologia Agraria y Alimentaria Jesús Martínez-Fernández

INIA: Instituto Nacional de Investigacion y Tecnologia Agraria y Alimentaria

Antonio Rodríguez

CISA-INIA https://orcid.org/0000-0002-0536-9902

Ana de la Torre

INIA: Instituto Nacional de Investigacion y Tecnologia Agraria y Alimentaria

\section{Research}

Keywords: Environmental risk assessment, agricultural land, pasture land, spatial analysis, crop, wild

Posted Date: November 16th, 2021

DOI: https://doi.org/10.21203/rs.3.rs-1049983/v1

License: (a) (i) This work is licensed under a Creative Commons Attribution 4.0 International License. Read Full License

Version of Record: A version of this preprint was published at Environmental Sciences Europe on April 14th, 2022. See the published version at https://doi.org/10.1186/s12302-022-00608-0. 


\section{Abstract \\ Background}

Antibiotics used to treat livestock species enter agricultural fields when they are excreted by grazing animals or are present in manure that is added to fields as fertiliser. In the European Union, the potential effects of such antibiotics on terrestrial plants must be evaluated following the standardised OECD 208 method, which specifies the crop and wild species that should serve as "sentinels" for assessing antibiotic exposure. The present study aimed to compare this approved list of sentinel species against crop and wild plant species actually present in agricultural and pasture lands in Mediterranean Europe in order to identify the most appropriate sentinel plants for the region. The study focused on Spain as a region representative of Mediterranean Europe. Georeferenced layers for wild plant species and cultivated areas (crops), livestock density and land cover were combined, and then selection criteria were applied, leading to the identification of sentinel crop species for agriculture and pasture scenarios.

\section{Results}

In the agriculture scenario, the sentinel crop species were barley, wheat, corn, sunflower, dried pie, alfalfa, vetch, oilseed rape and sugar beet; the sentinel wild species were Papaver rhoeas, Galium aparine and Chenopodium album. In the pasture scenario, sentinel wild species were Bromus tectorum, Agrostis capillaris, Trifolium pratense, Lotus corniculatus and Galium aparine. The following common weed species in field boundaries or in pasture lands also emerged as potential sentinel species for risk assessment, even though they are not listed in the OECD 208 method: Sonchus oleraceus, Avena sterilis, Dactylis glomerata, Hordeun murinum and Lolium rigidum.

\section{Conclusions}

The sentinel species identified in this study may be useful in risk assessment procedures covering Mediterranean Europe. The method developed for this study could be useful for identifying sentinel species for other geographical areas.

\section{Background}

Plant biodiversity plays a critical role in biogeochemical cycles and provides important ecosystem services [1, 2]. It is essential for capturing nutrients and retaining soil, and it provides habitats for animal species $[3,4]$, including pollination species and predators of pest species, serving as biological control against insects and weeds [5-8]. Biodiversity also provides humans with food, helps purify water supplies, generates oxygen and supplies raw materials for building, clothing, paper and other products [9]. 
There are around 500,000 species of land plants in the world [10], nearly $20 \%$ of which have been at risk of extinction since $1900[1,11]$. The drastic decrease in species diversity in Europe during the 20th century is closely linked to anthropogenic activities [12] that have led to habitat loss, fragmentation, degradation and overexploitation, species invasion, pollution, climate change and reduced availability of water $[2,13]$.

In fact, the largest contributor to biodiversity loss may be agriculture $[4,14,15]$, which exerts direct pressures on biodiversity [16]. Agricultural land area has increased about $300 \%$ since 1970, such that it now occupies a third of the world's surface land [17]. Indeed, $37 \%$ of the total land within the European Union (EU) is used for agriculture, with $12 \%$ of the total land serving as crop land to grow plants for human and animal consumption, while $25 \%$ serves as pasture land for grazing animals [4]. The area devoted to agriculture has increased in parallel with the cultivation of selected plant species and varieties in extensive, homogeneous landscapes. For example, a shift in many EU countries from semi-natural to cultivated grasslands that serve as pastures and meadows for livestock grazing or animal feed production has reduced plant biodiversity [18]. This biodiversity loss has resulted from grazing pressure, fertilisation, cutting management and the increasing dominance of competitive plant species $[12,18-20]$. At the same time, mechanised agricultural practices and use of fertilisers and pesticides have increased. All these factors have eroded the quantity and quality of habitat for many plants and animals, reducing their abundance and biodiversity [21-23].

Agricultural land is at high risk of contamination by antibiotics used to treat livestock species, and the antibiotics can harm crop plants [24-31] and wild plants [27, 28, 31, 32]. Antibiotics are poorly absorbed by animals, so $30-90 \%$ is excreted in manure that is added to the field immediately by grazing animals or later when it is added to fields as fertiliser [33-35]. Antibiotics pass from the manure into the soil. Studies often using higher antibiotic concentrations than those expected in agricultural soil $[36,37]$ have suggested that the compounds can harm plants mainly by delaying or inhibiting germination; inhibiting enzyme activity; stunting growth of shoots, roots, and stems; reducing the number of leaves and biomass production; and inducing necrosis and death [37, 38]. Minden et al. [38] observed delayed germination of crop and wild species after exposure to antibiotic concentrations typically found in agricultural and grassland soil. Ultimately, antibiotics may reduce plant species richness, abundance and/or diversity in treated fields as well as adjacent habitats, such as field margins and grasslands [38], with secondary effects on species at higher trophic levels [39].

The EU mandates assessment of the risk that antibiotics used to treat livestock may exert environmental effects (Directive 92/18/EC). This assessment should be carried out according to the standardised OECD 208 method, based on sentinel terrestrial plant species drawn from an approved list of 32 crop species or 52 wild species. Current recommendations are to include four or five dicotyledonous (dicot) and two or three monocotyledonous (monocot) crop species in the risk assessment [41], in order to adequately represent the types of plants grown on agricultural land fertilised with manure. However, we [42] and others (Küster and Adler, 2014) have argued for inclusion of the Poaceae family as the most representative crop family, given that cereals for human and animal consumption are grown on $50 \%$ of 
EU agricultural land [44]. We have also argued for including wild species in risk assessments in order to ensure the broadest protection of plant biodiversity [42].

In the present study, we drew on geographical information system mapping data to catalogue all crop species and wild plant species listed in the OECD 208 method on agricultural and pasture lands in a representative area of Mediterranean Europe. Then we applied selection criteria to the catalogue in order to identify the species potentially most suitable as sentinels for inclusion in risk assessments of environmental effects from antibiotics used to treat livestock. We selected Spain as a representative country in Mediterranean Europe. Most (85.5\%) of the country is found in the Mediterranean biome, and the remaining $14.5 \%$ belongs to the temperate biome [45], which covers the north of the Iberian Peninsula [46]. Spain is home to areas of high terrestrial biodiversity [47] as well as hotspots of valuable agricultural and pasture landscapes [48]. The country ranks second in the EU in terms of harvested area (around $25,000,000$ ha) and agricultural production ( 25 billion EUR) [49], and it contains the largest proportion (33\%) of all permanent grasslands in the EU $[50,51]$. Spain contains the second largest livestock population in the EU [44], and the animals are managed under a range of systems. The country ranks first in the EU for the number of pigs and third for the number of bovine animals, and it is the second-largest producer of pigs (4.6 million tonnes) and poultry (1.7 million tonnes) [49].

\section{Methods}

Major crop and wild plant species on agricultural and pasture lands where antibiotics are used to treat livestock were identified in two steps. First, agriculture and pasture scenarios receiving manure from intensively reared or grazing animals were identified and mapped. Second, data on crop species and wild plant species present in those scenarios were analysed to determine richness, diversity and evenness in the case of wild species, or number of cultivated hectares in the case of crop species. These steps are detailed in the subsequent paragraphs. All analyses were conducted using ArcMap 10.7 [52] and R 3.6.3 [53].

\section{- Definition of scenarios}

We considered the agriculture and pasture scenarios described by the "Guideline on Environmental Impact Assessment for Veterinary Medicinal Products" [54]. Agriculture scenarios were defined as crop fields that lie adjacent to intensive animal facilities and that receive manure from the intensively reared animals. Pasture scenarios were defined as lands covered with grass or herbage and grazed by livestock. In the agriculture scenario, we considered crops and wild species present in adjacent habitats of crop fields, such as field margins; in the pasture scenario, we considered only wild species because grazing animals consume forage, which is incompatible with crop production.

\section{- Mapping of agriculture and pasture scenarios}

The two scenarios were mapped by combining georeferenced layers on livestock density and land cover. To build density layers of intensively reared or grazing animals, georeferenced point data on cattle, pigs, 
and chickens were obtained from the Spanish Register of Livestock Holdings (REGA database, General Directorate of Livestock, Spanish Ministry of Agriculture, Fisheries and Food). This database includes data on whether the animals are raised indoors or outdoors. We assumed that "indoors" equated to "intensively reared", while "outside" equated to "grazing", except in the case of chickens, all of which we classified as intensively reared because chickens are typically grown in fenced yards and manure surplus is applied to agricultural fields [55]. In this way, we built five kernel density layers: intensively reared cattle, grazing cattle, intensively reared pigs, grazing pigs and intensively reared chickens.

We extracted population values from the livestock census, and we applied Silverman's Rule of Thumb [56] to define the search radius of each kernel density layer (Table A1):

$$
\text { Search radius } \left.=0.79 * \min \left(S D, \sqrt{\frac{1}{\ln (2)}} * D_{m}\right) * n^{-2}\right)
$$

where $S D$ is the standard distance; $D_{m}$, the median of the distances; and $n$, the total census.

We assumed that the probability that manure was applied to a given area was inversely proportional to the distance from an intensive animal facility, whose locations we extracted from the REGA database [57]. This reflects that farmers typically spread manure on their own land or on nearby land to avoid the costs and environmental disturbance (mainly outdoor smells) of transporting it farther away [58-60]. Similarly, we considered that the probability of grazing was inversely proportional to the distance from a primary animal location. In this way, each kernel animal density layer was categorised as having a low, medium or high manure load, with the three categories defined based on tertiles after exclusion of 0 values.

Layers of intensive crop and grassland cover were obtained from the Spanish Land Cover / Land Use Information System (SIOSE in Spanish; CNIG, 2014), after reclassifying the Inspire categories (CODIIGE). SIOSE is a polygon-based spatial dataset of land cover in the country at a scale of 1:25,000, and it is the basis for Spanish CORINE land cover data [62]. The dataset offers a minimum mapping unit of 2 ha for agricultural land, forests and natural areas. Land covers corresponding to crops were selected according to Piñeiro et al. [63] and the Spanish Ministry of Agriculture Food Security and Environment [64]. Land covers corresponding to grasslands were selected according to Ferrer et al. (2001; Table A2).

The livestock density layers were combined with the land cover layers using the mask tool in ArcGIS [52] in order to generate the agriculture and pasture scenarios. During this process, intensively reared animal layers were combined with the crop layer, whereas grazing animal layers were combined with the grassland layer. We constructed separate maps of the agriculture scenario for pigs, cattle and chickens; as well as separate maps of the pasture scenario for pigs and cattle. Each map classified areas by manure load. Altogether we considered 15 "subscenarios" defined by scenario (agriculture or pasture), animal species (pigs, cattle, chickens) and manure load category (low, medium, high) (Table 1). 
Table 1. Subscenarios in the area of study, defined by scenario, animal species and manure load

\begin{tabular}{|c|c|c|c|}
\hline Scenario & Animal species & Manure load & Subscenario \\
\hline \multirow[t]{9}{*}{ Agriculture } & \multirow[t]{3}{*}{ Pig } & High & Agri_Pig_H \\
\hline & & Medium & Agri_Pig_M \\
\hline & & Low & Agri_Pig_L \\
\hline & \multirow[t]{3}{*}{ Cattle } & High & Agri_Cattle_H \\
\hline & & Medium & Agri_Cattle_M \\
\hline & & Low & Agri_Cattle_L \\
\hline & \multirow[t]{3}{*}{ Chicken } & High & Agri_Chicken_H \\
\hline & & Medium & Agri_Chicken_M \\
\hline & & Low & Agri_Chicken_L \\
\hline \multirow[t]{6}{*}{ Pasture } & \multirow[t]{3}{*}{ Pig } & High & Past_Pig_H \\
\hline & & Medium & Past_Pig_M \\
\hline & & Low & Past_Pig_L \\
\hline & \multirow[t]{3}{*}{ Cattle } & High & Past_Cattle_H \\
\hline & & Medium & Past_Cattle_M \\
\hline & & Low & Past_Cattle_L \\
\hline
\end{tabular}

\section{- Identification of crop species present}

Data on crop species were obtained from the annual crop database of the Spanish Ministry of Agriculture, Fisheries and Food (General Subdirectorate for Analysis, Coordination and Statistics), which comprises data from all Spanish provinces across three databases covering general land use, herbaceous crops or woody crops. For each province, crops statistics are recorded in hectares at the municipality level. For the present study, data from 2015 were extracted from all but eight provinces, for which data were unavailable from that year. For these eight cases, municipality values were inferred based on the most recent available municipality values as well as provincial values from 2015.

In this way, we generated a "crop database" integrating general land use, herbaceous crops and woody crops in all municipalities of Spain. This database contained 166 crops from 39 families and altogether at least 150 different taxa. 
After overlaying the geographic information available, each municipality of the crop database was assigned to 1-5 of the 15 subscenarios (see Table 1). Within each scenario and animal species, a given municipality could belong to only a single manure load category, so it was assigned to the category showing the largest area in the municipality. Then, for the nine agriculture subscenarios, we calculated the mean percentage of total crop area covered by each crop and plant family, as well as the standard deviation and coefficient of variation in that percentage. Differences in crop percentages among the nine agriculture subscenarios were explored using linear mixed-effects (LME) models [66]. Crop types were considered as random factors in order to control for differences due to intrinsic characteristics of each crop category. Differences found to be significant with $95 \%$ confidence were further assessed using Tukey's post-hoc test in the emmeans package in $\mathrm{R}$ [67].

\section{- Identification of wild species present}

Data on wild plant population occurrences were obtained from the Global Biodiversity Information Facility (GBIF) database [68]. To be included, occurrence records had to have been deposited after 1980 and had to contain geographic coordinates to a precision of at least two decimal places in both latitude and longitude. Only non-crop species listed in Annex 2 of the OECD 208 method were considered as targeted species in this study. The 52 original taxa in the OECD method became 51 after species names were harmonised using the Germplasm Resources Information Network Taxonomy [69].

Georeferencing data on wild plant populations were screened for intraspecific spatial duplicates, defined as species occurrences less than $1 \mathrm{~km}$ apart $[70,71]$. Only one of such duplicate occurrences was retained in the dataset. The cleaned set of population occurrences included 69,883 records and was intersected with every map of the agriculture scenario (pigs, cattle and chickens) and pasture scenario (pigs and cattle) in order to derive the number of species, Simpson diversity [72], and Pielou's evenness [73]. For each subscenario within the agriculture and pasture scenarios, we calculated percentages of occurrence of each wild targeted species with respect to the total occurrence of all the targeted species in that subscenario. Differences in richness, diversity and evenness across subscenarios were explored using LME models [66]. Wild species were considered as random factors in order to control for differences in the incidence values due to intrinsic features of each species. When the effects were significant with $95 \%$ confidence, a post-hoc Tukey HSD test was performed using the emmeans package in $\mathrm{R}$ [67].

Finally, agriculture and pasture scenarios were overlapped with a geographical information system layer that included both the Spanish Sites of Community Importance network (belonging to the Natura 2000 network; Sundseth, 2008) and the Biosphere Reserves in Spain [75]. The objective was to estimate the area of these protected networks that was subjected to some type of livestock pressure and, therefore, exposed to antibiotics.

\section{Results}


- Mapping of agriculture and pasture scenarios

Our analysis indicated that forest and shrublands covered $38.89 \%$ of the total surface in Spain; arable crops, $36.69 \%$; and permanent grasslands, $16.71 \%$ (Table 2 ). In the agriculture scenario, $65.10 \%$ of the total land was arable, comprising crops $(53.43 \%$ ) and fallow lands $(11.67 \%)$, while $11.25 \%$ of the total land was natural grassland. In the pasture scenario, $21.43 \%$ of the total land was arable $(16.73 \%$ crops and $4.70 \%$ fallow lands), while $21.83 \%$ was natural grassland. An estimated $63.1-78.1 \%$ of total agricultural land area and $22.4-97.5 \%$ of total pasture land area could receive manure from livestock farms (Table A3).

Table 2

Main land cover statistics in agriculture and pasture scenarios in Spain

\begin{tabular}{|c|c|c|c|c|c|c|c|}
\hline & \multicolumn{3}{|c|}{ Agriculture scenario } & \multicolumn{3}{|c|}{ Pasture scenario } & \multirow{2}{*}{ 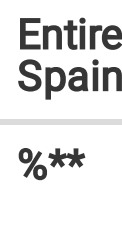 } \\
\hline & $\begin{array}{l}\% * \\
\text { Mean }\end{array}$ & $\begin{array}{l}\text { Std. } \\
\text { dev. }\end{array}$ & $\begin{array}{l}\text { Coeff. } \\
\text { var. }\end{array}$ & $\begin{array}{l}\% * \\
\text { Mean }\end{array}$ & $\begin{array}{l}\text { Std. } \\
\text { dev. }\end{array}$ & $\begin{array}{l}\text { Coe. } \\
\text { var. }\end{array}$ & \\
\hline Arable land & 65.10 & 1.95 & 0.03 & 21.43 & 5.84 & 0.27 & 36.69 \\
\hline Crops & 53.43 & 2.29 & 0.04 & 16.73 & 5.11 & 0.31 & 30.17 \\
\hline Herbaceus crops & 37.89 & 3.63 & 1.06 & 8.38 & 2.86 & 1.56 & 16.98 \\
\hline Woody crops & 15.55 & 3.95 & 0.25 & 8.35 & 4.05 & 0.49 & 13.18 \\
\hline Fallow lands & 11.67 & 0.93 & 0.08 & 4.70 & 1.45 & 0.31 & 6.52 \\
\hline Natural grasslands & 11.25 & 1.22 & 0.11 & 21.83 & 4.03 & 0.18 & 16.71 \\
\hline Mediterranean grasslands & 5.38 & 1.36 & 0.25 & 16.78 & 5.51 & 0.33 & 9.60 \\
\hline Natural meadows & 1.23 & 1.18 & 0.95 & 2.54 & 2.54 & 1.00 & 2.17 \\
\hline $\begin{array}{l}\text { Grazed uncultivated old } \\
\text { agricultural land }\end{array}$ & 4.64 & 0.63 & 0.14 & 2.52 & 2.72 & 1.08 & 4.95 \\
\hline Forests and shrublands & 15.69 & 1.94 & 0.12 & 50.39 & 2.64 & 0.05 & 38.89 \\
\hline $\begin{array}{l}\text { Neither natural nor agriculture } \\
\text { (rest of the area) }\end{array}$ & 7.96 & 0.81 & 0.10 & 6.34 & 0.54 & 0.09 & 7.71 \\
\hline \multicolumn{8}{|c|}{ * Calculated with respect to the total area of the municipalities belonging to each scenario } \\
\hline$\star \star$ Calculated with respect to th & area o & pain & & & & & \\
\hline
\end{tabular}

The pasture scenario showed the highest spatial coverage for cattle and the lowest coverage for pigs, and the two species were also associated with, respectively, the highest and lowest percentages of surface under high manure load (Table A3). These subscenarios concentrated in the western part of the country (Figures $1 \mathrm{~b}$ and $1 \mathrm{~d}$ ). 
In contrast, the agriculture scenario extended over flat areas throughout the country (Figures 1a, 1c and $1 \mathrm{e})$. The land surface under high manure load was twice as large for chickens as for cattle and pigs (Table A3).

\section{- Identification of crop species}

Mean percentages of total crop area covered by each crop family did not differ significantly across the three livestock species $(F=0.58 ; p=0.56)$ or three manure loads $(F=0.006 ; p=0.93)$. Therefore, the mean percentages for each crop family, as well as the associated standard deviations and coefficients of variation, were averaged across all agricultural subscenarios (Table 3 ). Herbaceous families covered $71.05 \%$ of crop land, with Poaceae the most abundant family (52.60\%), while woody families covered $28.94 \%$. 
Table 3

Minimum number of crops, minimum number of taxa and mean, standard deviation and coefficient of variation of the area covered by different crop families as a percentage of the total agricultural area in the agriculture scenario.

\begin{tabular}{|c|c|c|c|c|c|c|}
\hline \multirow[t]{2}{*}{ Family } & \multirow[t]{2}{*}{ Crop Type } & \multirow[t]{2}{*}{$\begin{array}{l}\text { Min. no. } \\
\text { of crops }\end{array}$} & \multirow[t]{2}{*}{$\begin{array}{l}\text { Min. no. } \\
\text { of taxa }\end{array}$} & \multicolumn{3}{|c|}{$\begin{array}{l}\text { Crop Area (\% total } \\
\text { area) }\end{array}$} \\
\hline & & & & Mean & $\begin{array}{l}\text { Std. } \\
\text { dev. }\end{array}$ & $\begin{array}{l}\text { Coeff. } \\
\text { var. }\end{array}$ \\
\hline Poaceae & $\begin{array}{l}\text { Herbaceous (except } \\
\text { cane) }\end{array}$ & 21 & 19 & 52.60 & 5.85 & 0.11 \\
\hline Fabaceae & $\begin{array}{l}\text { Herbaceous (except } \\
\text { carob) }\end{array}$ & 28 & 19 & 8.02 & 1.53 & 0.19 \\
\hline Convolvulaceae & Herbaceous & 1 & 1 & 0.01 & 0.00 & 0.84 \\
\hline Cyperaceae & Herbaceous & 1 & 1 & 0.00 & 0.00 & 1.56 \\
\hline Chenopodiaceae & Herbaceous & 5 & 5 & 0.40 & 0.13 & 0.33 \\
\hline Malvaceae & Herbaceous & 1 & 1 & 0.19 & 0.29 & 1.55 \\
\hline Linaceae & Herbaceous & 2 & 1 & 0.27 & 0.36 & 1.34 \\
\hline Cannabaceae & Herbaceous & 3 & 2 & 0.00 & 0.00 & 1.15 \\
\hline Asteraceae & Herbaceous & 7 & 7 & 6.14 & 2.71 & 0.44 \\
\hline Brassicaceae & Herbaceous & 7 & 6 & 0.84 & 0.36 & 0.43 \\
\hline Solanaceae & Herbaceous & 7 & 6 & 0.76 & 0.19 & 0.25 \\
\hline Apiaceae & Herbaceous & 4 & 3 & 0.08 & 0.02 & 0.30 \\
\hline Iridaceae & Herbaceous & 1 & 1 & 0.00 & 0.00 & 0.43 \\
\hline Lamiaceae & Herbaceous & 3 & 3 & 0.01 & 0.01 & 0.42 \\
\hline Caryophyllaceae & Herbaceous & 1 & 1 & 0.00 & 0.00 & 0.51 \\
\hline Cucurbitaceae & Herbaceous & 7 & 5 & 0.26 & 0.10 & 0.38 \\
\hline Asparagaceae & Herbaceous & 1 & 1 & 0.08 & 0.03 & 0.37 \\
\hline Amaryllidaceae & Herbaceous & 4 & 4 & 0.32 & 0.11 & 0.35 \\
\hline Agaricales & Herbaceous & 1 & 1 & 0.01 & 0.01 & 1.17 \\
\hline Sown meadows & Herbaceous & 1 & 2 & 0.74 & 0.81 & 1.10 \\
\hline $\begin{array}{l}\text { Groups of various } \\
\text { herbaceous ssp./families }\end{array}$ & Herbaceous & 13 & 13 & 0.32 & 0.07 & 0.21 \\
\hline Rutaceae & Woody & 6 & 6 & 1.86 & 0.83 & 0.44 \\
\hline
\end{tabular}




\begin{tabular}{|c|c|c|c|c|c|c|}
\hline \multirow[t]{2}{*}{ Family } & \multirow[t]{2}{*}{ Crop Type } & \multirow[t]{2}{*}{$\begin{array}{l}\text { Min. no. } \\
\text { of crops }\end{array}$} & \multirow[t]{2}{*}{$\begin{array}{l}\text { Min. no. } \\
\text { of taxa }\end{array}$} & \multicolumn{3}{|c|}{$\begin{array}{l}\text { Crop Area (\% total } \\
\text { area) }\end{array}$} \\
\hline & & & & Mean & $\begin{array}{l}\text { Std. } \\
\text { dev. }\end{array}$ & $\begin{array}{l}\text { Coeff. } \\
\text { var. }\end{array}$ \\
\hline Rosaceae & $\begin{array}{l}\text { Woody (except } \\
\text { strawberry and rose) }\end{array}$ & 15 & 15 & 6.32 & 4.41 & 0.70 \\
\hline Moraceae & Woody & 1 & 1 & 0.06 & 0.03 & 0.47 \\
\hline Annonaceae & Woody & 1 & 1 & 0.00 & 0.01 & 1.66 \\
\hline Punicaceae & Woody & 1 & 1 & 0.02 & 0.02 & 0.66 \\
\hline Lauraceae & Woody & 1 & 1 & 0.04 & 0.06 & 1.36 \\
\hline Musaceae & Woody & 1 & 1 & 0.01 & 0.01 & 1.55 \\
\hline Arecaceae & Woody & 1 & 1 & 0.00 & 0.01 & 2.37 \\
\hline Cactaceae & Woody & 1 & 1 & 0.00 & 0.00 & 0.53 \\
\hline Juglandaceae & Woody & 1 & 1 & 0.06 & 0.04 & 0.66 \\
\hline Betulaceae & Woody & 1 & 1 & 0.09 & 0.11 & 1.22 \\
\hline Vitaceae & Woody & 1 & 1 & 5.78 & 2.34 & 0.41 \\
\hline Oleaceae & Woody & 1 & 1 & 14.26 & 5.79 & 0.41 \\
\hline Capparaceae & Woody & 1 & 1 & 0.00 & 0.00 & 1.34 \\
\hline Rubiaceae & Woody & 1 & 1 & 0.00 & 0.00 & 3.00 \\
\hline Salicaceae & Woody & 1 & 1 & 0.00 & 0.00 & 1.45 \\
\hline Anacardiaceae & Woody & 1 & 1 & 0.00 & 0.00 & 0.00 \\
\hline $\begin{array}{l}\text { Groups of various woody } \\
\text { ssp/families }\end{array}$ & Woody & 11 & 12 & 0.44 & 0.12 & 0.28 \\
\hline TOTAL & & 166 & 150 & 100 & & \\
\hline
\end{tabular}

Most herbaceous families in the agriculture scenario matched those listed in the OECD 208 method (Table A4). Monocotyledonae were present in $74.43 \%$ of total area in the agriculture scenario, and dicotyledonae in the remaining $23.66 \%$. Only around $2 \%$ of crop land was covered by families not listed in the OECD 208 method. Thirteen species covered more than 1\% of crop land in the agriculture scenario; the most abundant individual species were barley (31.24\%) and wheat (24.96\%) (Table 4). 
Table 4

Ranking of herbaceous crops based on the percentage of total herbaceous crop area covered by each crop in the agriculture scenario and in Spain.*

\begin{tabular}{|c|c|c|c|c|c|c|c|c|}
\hline \multirow[t]{2}{*}{ Family } & \multirow[t]{2}{*}{ Crop } & \multicolumn{4}{|c|}{ Agriculture scenario } & \multicolumn{3}{|l|}{ Spain } \\
\hline & & Position & $\begin{array}{l}\% \\
\text { Mean }\end{array}$ & $\begin{array}{l}\text { Std. } \\
\text { dev. }\end{array}$ & $\begin{array}{l}\text { Coeff. } \\
\text { var. }\end{array}$ & Position & Area $(\mathrm{Ha})$ & $\begin{array}{l}\text { Area } \\
(\%)\end{array}$ \\
\hline Poaceae & $\begin{array}{l}\text { Barley } \\
\text { (Hordeum } \\
\text { vulgare L.) }\end{array}$ & 1 & 31.24 & 3.33 & 0.11 & 1 & 2.609 .699 & 28.28 \\
\hline Poaceae & $\begin{array}{l}\text { Wheat } \\
\text { (Triticum sp.) }\end{array}$ & 2 & 24.96 & 2.65 & 0.11 & 2 & 2.179 .058 & 23.61 \\
\hline Asteraceae & $\begin{array}{l}\text { Sunflower } \\
\text { (Helianthus } \\
\text { annuus L.) }\end{array}$ & 3 & 8.32 & 3.81 & 0.46 & 3 & 742258 & 8.04 \\
\hline Poaceae & $\begin{array}{l}\text { Corn } \\
\text { (Zea mays L.; } \\
\text { non-forage } \\
\text { corn) }\end{array}$ & 4 & 5.44 & 3.08 & 0.57 & 5 & 374525 & 4.06 \\
\hline Poaceae & $\begin{array}{l}\text { Oat } \\
\text { (Avena sativa } \\
\text { L.) }\end{array}$ & 5 & 4.19 & 0.79 & 0.19 & 4 & 484454 & 5.25 \\
\hline Fabaceae & $\begin{array}{l}\text { Alfalfa } \\
\text { (Medicago } \\
\text { sativa L.) }\end{array}$ & 6 & 3.72 & 2.17 & 0.58 & 7 & 257059 & 2.79 \\
\hline Poaceae & $\begin{array}{l}\text { Triticosecale } \\
\text { (Triticale) }\end{array}$ & 7 & 1.84 & 0.42 & 0.23 & 9 & 176589 & 1.91 \\
\hline Fabaceae & $\begin{array}{l}\text { Dried pie } \\
\text { (Pisum } \\
\text { sativum L.) }\end{array}$ & 8 & 1.68 & 0.43 & 0.26 & 10 & 162261 & 1.76 \\
\hline Poaceae & $\begin{array}{l}\text { Rye } \\
\text { (Secale } \\
\text { cereale L.) }\end{array}$ & 9 & 1.52 & 0.45 & 0.29 & 11 & 146946 & 1.59 \\
\hline Fabaceae & $\begin{array}{l}\text { Vetch } \\
\text { (Vicia sativa } \\
\text { L.) }\end{array}$ & 10 & 1.48 & 0.51 & 0.35 & 15 & 104400 & 1.13 \\
\hline
\end{tabular}




\begin{tabular}{|c|c|c|c|c|c|c|c|c|}
\hline \multirow[t]{2}{*}{ Family } & \multirow[t]{2}{*}{ Crop } & \multicolumn{4}{|c|}{ Agriculture scenario } & \multicolumn{3}{|l|}{ Spain } \\
\hline & & Position & $\%$ & $\begin{array}{l}\text { Std. } \\
\text { dev. }\end{array}$ & $\begin{array}{l}\text { Coeff. } \\
\text { var. }\end{array}$ & Position & Area (Ha) & $\begin{array}{l}\text { Area } \\
(\%)\end{array}$ \\
\hline Poaceae & $\begin{array}{l}\text { Winter cereals } \\
\text { for fodder }\end{array}$ & 11 & 1.45 & 0.35 & 0.24 & 8 & 184800 & 2.00 \\
\hline Fabaceae & $\begin{array}{l}\text { Forage vetch } \\
\text { (Vicia sativa } \\
\text { L.) }\end{array}$ & 12 & 1.32 & 0.60 & 0.45 & 12 & 120187 & 1.30 \\
\hline Poaceae & $\begin{array}{l}\text { Rice } \\
\text { (Oryza sativa } \\
\text { L.) }\end{array}$ & 13 & 1.07 & 0.80 & 0.75 & 13 & 109302 & 1.18 \\
\hline Various & $\begin{array}{l}\text { Sown } \\
\text { meadows }\end{array}$ & 14 & 1.02 & 1.03 & 1.01 & 6 & 284360 & 3.08 \\
\hline & $\begin{array}{l}\% \text { Total of } \\
\text { crops above } \\
1 \%\end{array}$ & & 89.24 & & & & & 85.98 \\
\hline
\end{tabular}

\section{- Identification of wild plant species}

Forty-six of the 51 taxa listed in Annex 3 of the OECD 208 method occur in Spain; no occurrence records with coordinates were obtained from the GBIF for Elymus canadensis L., Hordeum pusillum Nutt., Ipomoea hederacea Jacq., Senna obtusifolia (L.) H. S. Irwin \& Barneby, or Sesbania exaltata (Raf.) Rydb. Of the 46 taxa present in Spain, 42 occurred within all five combinations of scenarios and animal species. All the families containing the 42 plant species occurred in all five combinations of scenarios and animal species.

The 15 subscenarios showed similar values for richness, Simpson diversity index and Pielou index, with the exception of pig-rearing areas under medium or high manure load in the pasture scenario, which showed lower values for these parameters (Table A5). Nevertheless, no significant differences were found in richness, diversity or evenness across livestock species (Richness: $F=2.3 ; p=0.15$; Simpson: $F=2.06$; $p=0.17$; Pielou: $F=1.8 ; p=0.2$ ) or manure loads (Richness: $F=0.61 ; p=0.56$; Simpson: $F=0.3 ; p=0.75$; Pielou: $F=0.22 ; p=0.8$ ). Therefore, results were analysed further only at the level of the two scenarios.

In the agriculture scenario, Poaceae, Asteraceae and Polygonaceae were the families with the largest percentages of occurrence, and the most abundant species in these families were Echinochloa crus-galli (L.) P. Beauv., Xanthium spinosum L. and Rumex crispus L., respectively (Table 5). In the pasture scenario, Primulaceae, Poaceae and Rubiaceae were the families with the largest percentages of occurrence, with Bromus tectorum L. and Galium aparine L. the most abundant species. Even if the same family occupied the largest percentage of crop area in both the agriculture and pasture scenarios, the most abundant 
species from that family could differ. For example, the Poaceae species occupying the largest percentages were Echinochloa crus-galli and Digitaria sanguinalis (L.) Scop. in the agriculture scenario, but Bromus tectorum and Agrostis capillaris L. in the pasture scenario. In some cases, the same species from the same family dominated both the agriculture and pasture scenarios, as occurred with the Polygonaceae species Rumex crispus and Persicaria maculosa Gray (Table 5). 
Table 5

Mean, standard deviation and coefficient of variation of the percentage of presence of wild targeted species in agriculture and pasture scenarios

\begin{tabular}{|c|c|c|c|c|c|}
\hline & & Agriculture s & enario & Pasture sce & \\
\hline Family & Species & $\begin{array}{l}\text { Mean } \pm \text { Std. } \\
\text { dev. }\end{array}$ & $\begin{array}{l}\text { Coeff. } \\
\text { var. }\end{array}$ & $\begin{array}{l}\text { Mean } \pm \text { Std. } \\
\text { dev. }\end{array}$ & $\begin{array}{l}\text { Coeff. } \\
\text { var. }\end{array}$ \\
\hline Apiaceae & TOTAL & $0.44 \pm 0.11$ & 0.26 & $0.54 \pm 0.40$ & 0.75 \\
\hline & Torilis japonica (Houtt.) DC. & $0.44 \pm 0.11$ & 0.26 & $0.54 \pm 0.40$ & 0.75 \\
\hline Asteraceae & TOTAL & $11.25 \pm 1.19$ & 0.11 & $9.35 \pm 2.43$ & 0.26 \\
\hline & Bellis perennis $\mathrm{L}$. & $2.59 \pm 0.19$ & 0.07 & $4.05 \pm 0.80$ & 0.20 \\
\hline & Centaurea cyanus L. & $1.73 \pm 0.43$ & 0.25 & $0.83 \pm 0.53$ & 0.64 \\
\hline & Centaurea nigra L. & $1.01 \pm 0.55$ & 0.55 & $1.49 \pm 1.44$ & 0.97 \\
\hline & Inula helenium L. & $0.14 \pm 0.06$ & 0.45 & $0.08 \pm 0.09$ & 1.12 \\
\hline & Leontodon hispidus L. & $0.80 \pm 0.18$ & 0.23 & $1.08 \pm 0.91$ & 0.85 \\
\hline & Rudbeckia hirta L.* & & & $0.00 \pm 0.00$ & 1.60 \\
\hline & Solidago canadensis $\mathrm{L}$. & $0.12 \pm 0.12$ & 0.94 & $0.06 \pm 0.06$ & 1.13 \\
\hline & Xanthium spinosum $\mathrm{L}$. & $3.41 \pm 0.77$ & 0.23 & $1.26 \pm 0.61$ & 0.48 \\
\hline & Xanthium strumarium L. & $1.45 \pm 0.38$ & 0.27 & $0.50 \pm 0.20$ & 0.40 \\
\hline Brassicaceae & TOTAL & $0.74 \pm 0.37$ & 0.50 & $1.06 \pm 1.01$ & 0.95 \\
\hline & Cardamine pratensis $\mathrm{L}$. & $0.74 \pm 0.37$ & 0.50 & $1.06 \pm 1.01$ & 0.95 \\
\hline Caryophyllaceae & TOTAL & $0.44 \pm 0.28$ & 0.64 & $0.58 \pm 0.42$ & 0.72 \\
\hline & $\begin{array}{l}\text { Silene flos-cuculi (L.) Greuter \& } \\
\text { Bourdet }\end{array}$ & $0.44 \pm 0.28$ & 0.64 & $0.58 \pm 0.42$ & 0.72 \\
\hline Chenopodiaceae & TOTAL & $6.19 \pm 0.66$ & 0.11 & $2.65 \pm 1.28$ & 0.48 \\
\hline & Chenopodium album L. & $6.19 \pm 0.66$ & 0.11 & $2.65 \pm 1.28$ & 0.48 \\
\hline Cyperaceae & TOTAL & $1.59 \pm 0.53$ & 0.33 & $0.47 \pm 0.33$ & 0.71 \\
\hline & Cyperus rotundus $\mathrm{L}$. & $1.59 \pm 0.53$ & 0.33 & $0.47 \pm 0.33$ & 0.71 \\
\hline Fabaceae & TOTAL & $9.06 \pm 0.73$ & 0.08 & $8.64 \pm 4.38$ & 0.51 \\
\hline & Lotus corniculatus L. & $4.32 \pm 0.43$ & 0.10 & $4.00 \pm 2.69$ & 0.67 \\
\hline
\end{tabular}




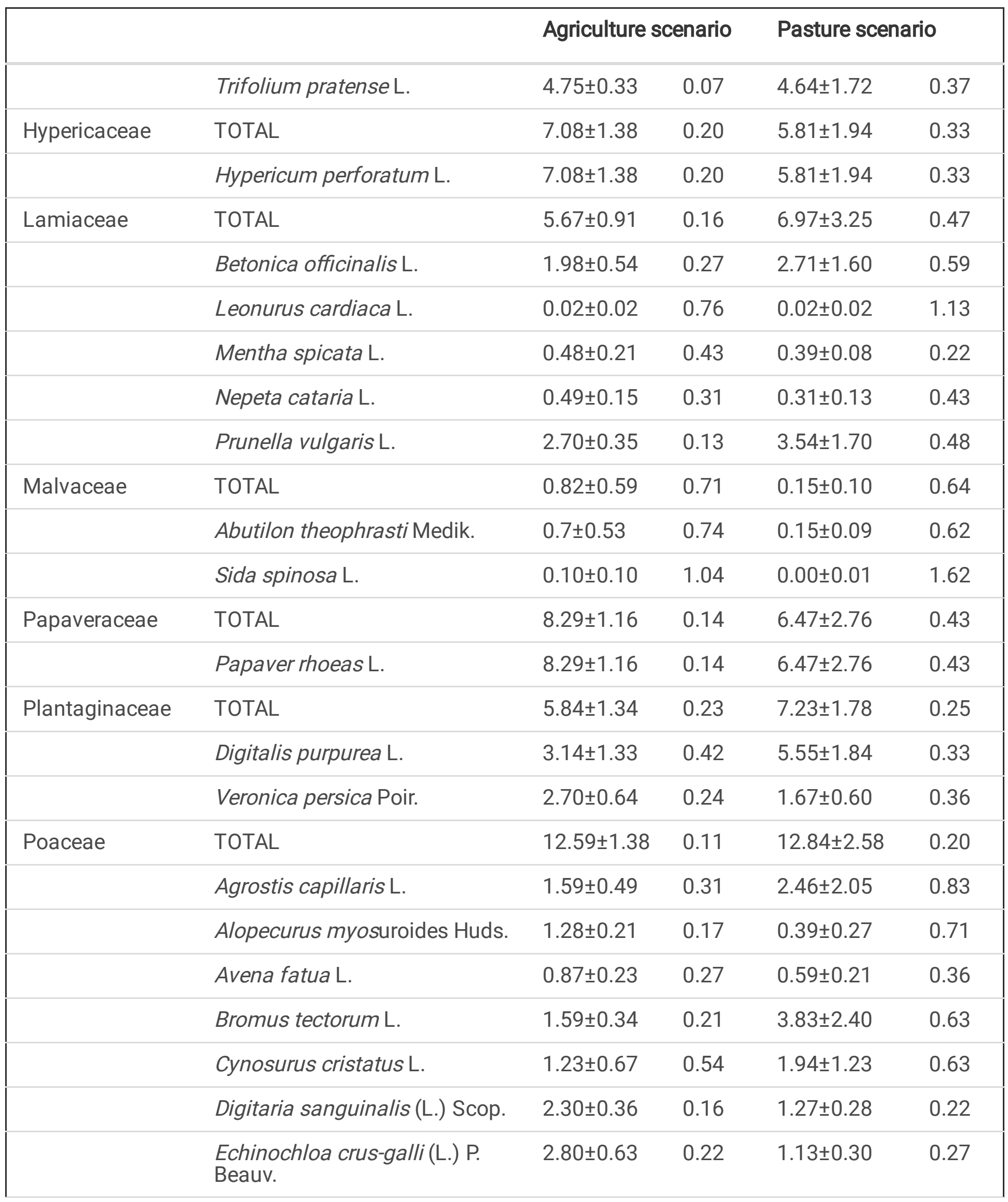

* Information about five populations was obtained from the Global Biodiversity Information Facility (GBIF) database [68]: one in the Past_Cattle_H subscenario, one in the Past_Cattle_M subscenario and three in the agricultural and pasture scenarios 


\begin{tabular}{|c|c|c|c|c|c|}
\hline & \multirow[b]{2}{*}{ Festuca pratensis Huds. } & \multicolumn{2}{|c|}{ Agriculture scenario } & \multicolumn{2}{|c|}{ Pasture scenario } \\
\hline & & $0.27 \pm 0.19$ & 0.71 & $0.35 \pm 0.36$ & 1.02 \\
\hline & Phleum pratense L. & $0.96 \pm 0.28$ & 0.29 & $0.89 \pm 0.68$ & 0.77 \\
\hline \multirow[t]{6}{*}{ Polygonaceae } & TOTAL & $11.00 \pm 1.75$ & 0.16 & $8.03 \pm 1.07$ & 0.13 \\
\hline & $\begin{array}{l}\text { Fallopia convulvulus (L.) Á. } \\
\text { Löve }\end{array}$ & $1.54 \pm 0.41$ & 0.27 & $0.87 \pm 0.51$ & 0.59 \\
\hline & $\begin{array}{l}\text { Persicaria lapathifolia (L.) } \\
\text { Delarbre }\end{array}$ & $2.16 \pm 0.30$ & 0.14 & $1.30 \pm 0.40$ & 0.31 \\
\hline & Persicaria maculosa Gray & $2.70 \pm 0.49$ & 0.18 & $1.60 \pm 0.35$ & 0.22 \\
\hline & $\begin{array}{l}\text { Persicaria pensy/vanica (L.) M. } \\
\text { Gómez }\end{array}$ & $0.01 \pm 0.01$ & 1.11 & $0.00 \pm 0.01$ & 2.45 \\
\hline & Rumex crispus L. & $4.59 \pm 0.64$ & 0.14 & $4.26 \pm 1.26$ & 0.30 \\
\hline \multirow[t]{2}{*}{ Primulaceae } & TOTAL & $8.55 \pm 1.88$ & 0.22 & $16.48 \pm 11.77$ & 0.71 \\
\hline & $\begin{array}{l}\text { Lysimachia arvensis (L.) U. } \\
\text { Manns \& Anderb. }\end{array}$ & $8.55 \pm 1.88$ & 0.22 & $16.48 \pm 11.77$ & 0.71 \\
\hline \multirow[t]{2}{*}{ Ranunculaceae } & TOTAL & $0.99 \pm 0.28$ & 0.28 & $1.26 \pm 0.99$ & 0.78 \\
\hline & Ranunculus acris $\mathrm{L}$. & $0.99 \pm 0.28$ & 0.28 & $1.26 \pm 0.99$ & 0.78 \\
\hline \multirow[t]{2}{*}{ Rosaceae } & TOTAL & $1.41 \pm 0.45$ & 0.32 & $2.02 \pm 1.41$ & 0.70 \\
\hline & Geum urbanum L. & $1.41 \pm 0.45$ & 0.32 & $2.02 \pm 1.41$ & 0.70 \\
\hline \multirow[t]{3}{*}{ Rubiaceae } & TOTAL & $7.73 \pm 1.42$ & 0.18 & $9.44 \pm 2.71$ & 0.29 \\
\hline & Galium aparine L. & $6.83 \pm 1.39$ & 0.20 & $8.25 \pm 3.32$ & 0.40 \\
\hline & Galium mollugo L. & $0.90 \pm 0.29$ & 0.33 & $1.19 \pm 0.76$ & 0.64 \\
\hline
\end{tabular}

The coefficients of variation in the percentages of occurrence of the targeted wild species were low and ranged from 0.20 to 2.45 at the species level, and from 0.13 to 0.95 at the family level (Table 5).

We detected livestock pressure on $25 \%$ of the lands protected within the Spanish Sites of Community Importance or the Biosphere Reserves (Figure 2). In fact, $75 \%$ of these protected areas was estimated to be exposed to antibiotics in the pasture scenario (Figure 2). The subscenarios predicting the largest areas of exposure risk in protected lands were the cattle-rearing lands under low or medium manure load in the pasture scenario (Table A6). The subscenarios predicting the smallest areas of exposure risk were pigrearing lands under high manure load in the agriculture and pasture scenarios. 


\section{Discussion}

\section{- Agriculture and pasture scenarios and subscenarios}

Our maps for agriculture and pasture subscenarios (Figure 1) reveal a heterogeneous "patchwork" reflecting the diverse influences on agricultural and livestock activities in Spain, which include bioclimatic, socioeconomic and policy factors $[46,76,77]$.

Geographical areas under high manure load in our study correspond to high productive regions of arable land, pasture and meadows [78]. In the agriculture scenario, areas under high manure load were located predominantly in the Iberian central high plateau and the Ebro River Basin, which feature mainly arable lands with herbaceous crops, especially cereals (Figures 1a, 1c and 1e). We also observed areas under high manure load in southern Spain and along the Mediterranean coast that were associated with rearing of chickens (Figure 1e). The wider distribution of chickens than of cattle or pigs may reflect the stronger economic constraint on chicken farms to be closer to markets, rather than the influence of climatic or other environmental factors [79].

In the cattle pasture scenario, geographical areas under high manure load were present in the humid northern provinces, especially along the north and central mountain ranges, which are characterised by rich pastures and meadows. Such areas lay also in the west and southwest of the Peninsula, where pasture lands known as "dehesas" are abundant [51]. Dehesas, an agroforestry system that harmoniously combines pastures and trees, are one of the most ecologically valuable and economically important rural landscapes on the Iberian Peninsula [78]. The distribution of dehesas coincides exactly with that of pig-rearing pastures in our study (Figure 1b), even though cattle also graze on dehesas [80].

The agriculture scenario showed extensive surface devoted to arable land, mainly for herbaceous crops such as barley and wheat, and to a lesser extent for woody crops, mainly olive, vineyards and fruit trees. In contrast, more than two thirds of the land surface in the pasture scenario was woody vegetation (forest and shrublands) and natural grass. Natural grasslands, which include meadows, rough grassland and rough grazing rangeland, are dominated by herbaceous species and are the main food source for extensively managed livestock in Spain [51]. Shrublands and open forests also play an essential role in livestock farming when green grass is in short supply [51].

\section{- Monocotyledonous crop species in the agriculture scenario}

Plant toxicity assays are designed to be rapid, simple and reproducible, which helps explain why the OECD 208 method includes only herbaceous, not woody, species as sentinels for assessing risk of environmental effects due to antibiotics given to livestock. Indeed, herbaceous crop plants are the focus of efforts to fertilise arable lands with manure. In England and Wales, manure is applied to arable crops of cereals (wheat, barley and maize), sugar beet and potatoes, as well as to land for grazing and silage $[59,60]$. In France, $36.5 \%$ of total manure used for fertiliser is spread onto grassland, $39.6 \%$ onto land for maize, $12.9 \%$ onto land for cereals and $7.9 \%$ onto land for oilseed or protein crops [58]. 
We found that in Spain, the Monocotyledonae group and concretely the Poaceae family dominated herbaceous crop species in the agriculture scenario (Table 4). This reflects that cereals cover more land in Spain than any other crop, occupying $71 \%$ of the herbaceous crop area. This broad distribution reflects, in part, the plants' adaptability to different soils and climatic conditions. At the national level, cereals account for $7.1 \%$ of agrarian production and $12.3 \%$ of vegetable production [81]. We found that barley, wheat and corn occupied the top positions in the agriculture scenario (Table 4), consistent with their status as the main cereals produced in Spain [81]. The situation is likely to be similar at the level of the entire EU, which is the largest wheat and barley producer worldwide and which accounts for $6 \%$ of global corn production [81]. Wheat, barley and corn are included in Annex 2 of the OECD method.

The cereals oat, triticale, rye and rice are also cultivated in Spain and all were identified in the agriculture scenario, but each of them accounted for less than $5 \%$ of the herbaceous crop area. A similar pattern occurs at the EU level, where rye accounts for $2.0 \%$ and rice for $0.4 \%$ of the total arable land [82]. All these cereal species except triticale are listed in Annex 2 of the OECD 208 method. Triticale is cultivated for winter cereal-legume forage intercrops, but legumes are necessarily more abundant in such intercrops in order to maintain feeding values [83].

The Liliaceae family was found to occupy $0.5 \%$ of the herbaceous crop area in the agriculture scenario, with the most abundant crops being onion $(0.25 \%)$ and garlic $(0.21 \%)$. Onion is the only species of this family listed in Annex 2 of the OECD 208 method, and it is the second most cultivated fresh vegetable in the EU. However, animal manure is not suitable for fertilising onion or other horticultural crops because bacteria, parasites and viruses in manure can contaminate the food supply [84] and lead to bioaccumulation of contaminants such as veterinary antibiotics in stems and roots [85, 86]. Nevertheless, manure can be composted for a long period and the resulting fertiliser can be considered safe for use on vegetable crops [87].

\section{- Dicotyledonous crop species in the agriculture scenario}

Dicotyledonae herbaceous crop species covered approximately $25 \%$ of the agriculture scenario (Table A4). The families Fabaceae and Asteraceae clearly predominated (19\%), occupying the top four positions by land cover: an Asteraceae species (sunflower), followed by three Fabaceae species of alfalfa, vetch, and dried pie (Table 4). All these species except alfalfa are included in Annex 2 of the OECD 208 method.

Sunflower is an oilseed species, so it is used for human and animal consumption, fuel and industrial purposes, giving it high economic value [88]. Oilseed species come from different Dicotyledonae families: rape, which accounts for $59 \%$ of total oilseed production in the $\mathrm{EU}$, comes from the Brasicaceae family; sunflower, from Asteraceae; and soybean, from Fabaceae (EC, 2021). Of these oilseed species, only sunflower and rape have a notable presence in Spain [89]; rape occupied $0.92 \%$ of the agriculture scenario, placing it at 15th position in terms of land cover.

Alfalfa and vetch are fodder crops, although vetch is also used for human consumption. Fodder crops comprise legumes, cereals, sown meadows and other crops (Eurostat, 2020b). Fodder crops are 
important for extensively managed livestock in Spain [51]. Among the four most abundant fodder species in our analysis, alfalfa is by far the most important in Spain (Table 4) and the EU [51]. Vetch species are also frequently used in combination with a cereal such as oat or barley or with a pasture grass such as Italian ryegrass [51, 83].

Dried pie is a protein-rich crop, and such crops are a major source of amino acids for human and animal nutrition. Dried pie ranked eighth for land cover in the agriculture scenario (Table 7), and it is the most widespread protein-rich crop in Spain [89]. At the EU level, pea, bean and lupine are major cultivated protein crops [90].

Among the other dicot families and crop species listed in Annex 2 of the OECD 208 method, only the Chenopodiaceae family and sugar beet species have some importance in Spanish agriculture, accounting for $0.5 \%$ of herbaceous crops (20th position). The EU is the world's leading producer of sugar beet, accounting for around 50\% of global production [90]. Most sugar beet in the EU is grown in northern Europe, where the climate is more suitable for this crop [91].

\section{- Sentinel crop species in the agriculture scenario}

The European Medicines Agency recommends that assessments of risk from veterinary antibiotics include plant species that are grown on agricultural land that are fertilised with manure [92]. It would also be advisable to take into account the intrinsic susceptibility of plant species to antibiotics [37], but such data are nearly absent from the literature [93]. Thus, given the currently available data, the best species for risk assessments may be those that are abundant on agricultural land and that receive manure fertiliser.

Given that Poaceae is the crop family with the largest area in the agriculture scenario, it would be advisable to consider at least two monocot species from among barley, wheat or corn in the risk assessment of antibiotics used to treat livestock species. Such assessment should also consider the dicot species of sunflower (Asteraceae) as soilseed, dried pie (Fabaceae) as a protein-rich crop, as well as alfalfa and vetch (Fabaceae) as fodder crops. It may also be helpful to consider the oilseed rape (Brassicaceae) and sugar beet (Chenopodiaceae), since both are widely cultivated in the EU.

\section{- Wild species in agriculture and pasture scenarios}

The Mediterranean Basin is one of the 25 biodiversity hotspots around the globe where many endemic species are losing their habitat [94]. The only hotspots of importance in Europe are the Mediterranean Basin and the Caucasus, both of which are extremely vulnerable to climate change [95]. As a representative region of the Basin, Spain has among the greatest diversity of ecosystems, habitats and natural species in the EU, housing more than half of the Union's species of vertebrates and vascular plants as well as $65 \%$ of its priority habitats [4].

Most pasture areas serve for grazing by livestock and/or wild ungulates, but they also provide other valuable regulation and cultural ecosystem services [78]. Spanish pasture lands contain an abundance of 
Poaceae species as well as numerous other families catalogued in the Habitats of Community Interest under the EU Habitats Directive (92/43/EEC) (San Miguel et al., 2016). Our results highlight Lysimachia arvensis (L.) U. Manns \& Anderb. (Primulaceae) and Galium aparine (Rubiaceae) as the most frequent species (Table 5). Lysimachia arvensis has been reported to cause cattle death in Uruguay and potentially also sheep death in Australia [96]. In contrast, cleaver (Galium aparine) may support plant biodiversity [97]. The following species appear in Annex 3 of the OECD method and have been described as most abundant in Spanish pasture lands [51], which may make them useful for assessing risk from veterinary antibiotics: Agrostis, Bromus and Festuca within the Poaceae family, as well as Trifolium and Lotus within the Fabaceae family. However, in the pasture scenario, species from this genera accounted for only $2-5 \%$ of all wild species, while Festuca species accounted for $<1 \%$. These species may therefore not be sufficiently representative. In other words, Annex 3 does not include most of the dominant plant species on Mediterranean pasture lands.

Arable field margins provide a wide range of ecosystem services in rural landscapes and limit the negative effects of competitive and dominant species on crop productivity [98]. Plant diversity in these habitats has declined in recent decades due to agricultural intensification [97, 99-102]. Thus, one of the main challenges of agriculture worldwide is to balance crop productivity and biodiversity maintenance.

In typical Mediterranean cereal cropping systems in the Guadalquivir river basin in southern Spain, Pallavicini et al. (2020) identified 306 weed species, of which only 10 are catalogued in the OECD Annex 3. Among these catalogued species, the four most abundant were also among the five most frequent in our agriculture scenario: Lysimachia arvensis, Galium aparine, Papaver rhoeas L. and Chenopodium album L. Similarly, in cereal fields of the Ebro basin in northeastern Spain, Cirujeda et al. (2011) identified 175 weed species. Only 6 of the most abundant species (occurring in $>10 \%$ of the surveyed fields) are included in the OECD Annex 3, with Papaver rhoeas the most abundant. This similarity in most abundant species between our mapped scenarios and previous fieldwork suggests that our analysis based on the GBIF data is reliable.

In addition, our results indicate the relevance of Hypericum perforatum L., the fourth most frequent wild species in Spain among those in Annex 3 (Table 5). This species was not inventoried by Pallavicini et al. (2020) or Cirujeda et al (2011), which may indicate that this moisture-loving species does not prefer the hot, dry conditions in the Ebro and Guadalquivir river basins.

Cirujeda et al. $(2011,2019)$ identified several extremely abundant weed species in Spanish cereal fields not included in the OECD 208 method, including Avena sterilis, Convolvulus arvensis, Dactylis glomerata L., Lolium rigidum and Sonchus oleraceus $L$. The role of weeds in supporting biological diversity within crop fields has been studied by Marshall (2003) and Storkey (2006). From a total of 32 species identified in those studies as important for biodiversity, only five are included in Annex 3 of the OECD 208 method. All of them were present in our agriculture scenario: Chenopodium album (Chenopodiaceae), Galium aparine (Rubiaceae) and Papaver rhoeas (Papaveraceae) accounted for $5-8 \%$ of the total occurrence 
records of all targeted species in this scenario, while Persicaria maculosa and Fallopia convolvulus (Polygonaceae) accounted for $1.5-2.7 \%$ of the total occurrence records (Table 5).

\section{- Sentinel wild species in agriculture and pasture scenarios}

Our analysis suggests that assessments of risk from veterinary antibiotics should take into account Papaver rhoeas, Galium aparine and Chenopodium album as sentinel wild species. These species are important for biodiversity and they are abundant among targeted wild species in our agriculture scenario.

Our analysis of the pasture scenario suggests that risk assessments should not take into account Lysimachia arvensis. Even though this species belongs to the most abundant family (Primulaceae), the plant has been linked to livestock death (Roche et al., 2012). Instead, our analysis suggests that risk assessments should include Bromus tectorum or Agrostis capillaris from the Poaceae family, as well as Trifolium pratense or Lotus corniculatus from the Fabaceae family. All these species are relatively abundant among targeted wild species and they are dominant in Mediterranean grasslands [51]. The species Galium aparine (Rubiaceae) could also be considered, since it was the second most frequent species in our pasture scenario and it can support biodiversity.

While all the above mentioned species have been listed in Annex 3 of the OECD 208 method, there are other weed species at the margins of arable fields and on pasture lands that could be useful in assessments of risk from veterinary antibiotics but are not listed in Annex 3. These species may include those identified as the most frequent in surveys of field boundaries $[99,100,102]$ and pasture lands (San Miguel et al., 2016) and that support biodiversity or food security. For example, Sonchus oleraceus is one of the most frequent weed species at field boundaries in Spain [99], and it is important for biodiversity [101]. Some Poaceae species, such as Avena sterilis, Dactylis glomerata, Hordeun murinum and Lolium rigidum, are also frequent and are included on the Prioritised Spanish Checklist of Crop Wild Relatives [103], which compiles alternative crop species crucial to ensure food security.

The identification of sentinel species may be especially beneficial for biodiversity conservation within the Spanish Sites of Community Importance network and Biosphere Reserves, given that up to $75 \%$ of these protected areas may be vulnerable to phytotoxic effects from veterinary antibiotics, according to our pasture scenario. Future work to consider new "sentinel" species not currently in Annex 3 will also need to evaluate how feasible it is to develop standardised testing protocols akin to the OECD 208 method. This will depend on the commercial availability of seeds and whether they meet the conditions for laboratory assays (e.g. germination rate $\geq 70 \%$ and survival rate $\geq 90 \%$ ).

\section{Conclusions}

Based on geographical information systems mapping, we propose the inclusion of certain sentinel crop and wild species in assessments of environmental risk from antibiotics used to treat livestock in Mediterranean Europe. By combining georeferenced layers on livestock density and land cover, we generated agriculture and pasture scenarios for Spain as a representative country in Mediterranean 
Europe. Then we identified which of the crop and wild plant species in the OECD 208 method were present in the scenarios. Finally, we assessed the suitability of the species for risk assessments based on various criteria. This led us to propose barley, wheat, corn, sunflower, dried pie, alfalfa, vetch, oilseed rape and sugar beet as sentinel crop species in the agricultural scenario. As sentinel wild species, we propose Bromus tectorum, Agrostis capillaris, Trifolium pratense, Lotus corniculatus and Galium aparine in the pasture scenario; and Papaver rhoeas, Galium aparine and Chenopodium album in the agriculture scenario. We also urge the consideration of several weed species common at field boundaries or on pasture lands that are not listed in the OECD 208 method but that contribute substantially to biodiversity.

\section{Abbreviations}

GBIF: Global Biodiversity Information Facility

LME: linear mixed-effects

REGA: Spanish Register of Livestock Holdings

\section{Declarations}

Ethics approval and consent to participate: Not applicable

Consent for publication: Not applicable

Availability of data and material: The datasets used and/or analysed during the current study are available from the corresponding author on reasonable request. Data from Spanish Register of Livestock Holdings (REGA) are not available due to data privacy laws.

Competing interests: The authors declare that they have no competing interests.

Funding: This work was supported by the Spanish Ministry of Science and Innovation (RTI208_095586_B_C21)

\section{Authors' contributions}

RMG: contributed in Formal analysis, Investigation, and Writing of the Original Draft

JFM contributed in Methodology, Formal analysis, Resources, Data Curation, Visualization and Writing Original Draft

AR contributed in Methodology and Formal analysis -kernel models, geostatistical procedures and mixed effects models-. He collaborated in the Writing Review and Editing.

AT responsible of Conceptualization, provision of data and Writing, Review and Editing 
Acknowledgements: Not applicable

\section{References}

1. Corlett RT (2016) Plant diversity in a changing world: Status, trends, and conservation needs. Plant Divers 38:10-16

2. Franklin J, Serra-Diaz JM, Syphard AD, Regan HM (2016) Global change and terrestrial plant community dynamics. Proc Natl Acad Sci 113:3725-3734.

https://doi.org/10.1073/PNAS.1519911113

3. Haddad NM, Crutsinger GM, Gross K et al (2009) Plant species loss decreases arthropod diversity and shifts trophic structure. Ecol Lett 12:1029-1039. https://doi.org/10.1111/j.14610248.2009.01356.x

4. ECA (2019) European Court of Auditors. Biodiversity in farming Audit preview

5. Blüthgen N, Klein AM (2011) Functional complementarity and specialisation: The role of biodiversity in plant-pollinator interactions. Basic Appl Ecol 12:282-291. https://doi.org/10.1016/J.BAAE.2010.11.001

6. Potts SG, Petanidou T, Roberts S et al (2006) Plant-pollinator biodiversity and pollination services in a complex Mediterranean landscape. Biol Conserv 129:519-529. https://doi.org/10.1016/J.BIOCON.2005.11.019

7. Carvalheiro LG, Seymour CL, Veldtman R, Nicolson SW (2010) Pollination services decline with distance from natural habitat even in biodiversity-rich areas. J Appl Ecol 47:810-820. https://doi.org/10.1111/j.1365-2664.2010.01829.x

8. Kaluza BF, Wallace H, Keller A et al (2017) Generalist social bees maximize diversity intake in plant species-rich and resource-abundant environments. Ecosphere 8:e01758. https://doi.org/10.1002/ecs2.1758

9. Cardinale BJ, Matulich KL, Hooper DU et al (2011) The functional role of producer diversity in ecosystems. Am J Bot 98:572-592. https://doi.org/10.3732/ajb.1000364

10. Pullaiah T, Bahadur B, Krishnamurthy KV (2015) Plant biodiversity. In: Bahadur B, Rajam MV, Sahijram L, Krishnamurthy KV (eds) Plant Biology and Biotechnology: Plant Diversity, Organization, Function and Improvement. Springer India, Telangana, India, pp 177-195

11. RBG Kew (2016) The State of the World's Plants Report - 2016

12. Luoto M, Rekolainen S, Aakkula J, Pykälä J (2003) Loss of Plant Species Richness and Habitat Connectivity in Grasslands Associated with Agricultural Change in Finland. Ambio 32:447-452. https://doi.org/10.1579/0044-7447-32.7.447

13. Slingenberg $A$, Braat $L$, Windt $H$, Van Der et al (2009) Study on understanding the causes of biodiversity loss and the policy assessment framework. rotterdam

14. Dudley N, Alexander S (2017) Agriculture and biodiversity: a review. Biodiversity 18:45-49. https://doi.org/10.1080/14888386.2017.1351892 
15. Le Roux JJ, Hui C, Castillo ML et al (2019) Recent Anthropogenic Plant Extinctions Differ in Biodiversity Hotspots and Coldspots. Curr Biol 29:2912-2918. https://doi.org/10.1016/j.cub.2019.07.063. .e2

16. Kok MTJ, Alkemade R, Bakkenes M et al (2018) Pathways for agriculture and forestry to contribute to terrestrial biodiversity conservation: A global scenario-study. Biol Conserv 221:137-150. https://doi.org/10.1016/j.biocon.2018.03.003

17. IPBES (2019) Global assessment report on biodiversity and ecosystem services of the Intergovernmental Science-Policy Platform on Biodiversity and Ecosystem Services. Bonn, Germany

18. Plantureux S, Peeters A, Mccracken D (2005) Biodiversity in intensive grasslands: Effect of management, improvement and challenges. Agron Res 3:153-164

19. Czarniecka-Wiera M, Kącki Z, Chytrý M, Palpurina S (2019) Diversity loss in grasslands due to the increasing dominance of alien and native competitive herbs. Biodivers Conserv 28:2781-2796. https://doi.org/10.1007/s10531-019-01794-9

20. Lesschen JP, Elbersen B, Hazeu G et al (2014) Defining and classifying grasslands in Europe. Wageningen

21. Emmerson M, Morales MB, Oñate JJ et al (2016) Chapter Two - How Agricultural Intensification Affects Biodiversity and Ecosystem Services. In: Dumbrell AJ, Kordas RL, Woodward G (eds) LargeScale Ecology: Model Systems to Global Perspectives. Academic Press, pp 43-97

22. McLaughlin A, Mineau $P$ (1995) The impact of agricultural practices on biodiversity. Agric Ecosyst Environ 55:201-212. https://doi.org/10.1016/0167-8809(95)00609-V

23. Martin AE, Collins SJ, Crowe S et al (2020) Effects of farmland heterogeneity on biodiversity are similar to-or even larger than-the effects of farming practices. Agric Ecosyst Environ 288:106698. https://doi.org/10.1016/j.agee.2019.106698

24. Rede D, Santos LHMLM, Ramos S et al (2019) Individual and mixture toxicity evaluation of three pharmaceuticals to the germination and growth of Lactuca sativa seeds. Sci Total Environ 673:102109. https://doi.org/10.1016/j.scitotenv.2019.03.432

25. Tasho RP, Ryu SH, Cho JY (2020) Effect of sulfadimethoxine, oxytetracycline, and streptomycin antibiotics in three types of crop plants-root, leafy, and fruit. Appl Sci 10:1111. https://doi.org/10.3390/app10031111

26. Litskas VD, Karamanlis XN, Prousali SP, Koveos DS (2019) The xenobiotic doxycycline affects nitrogen transformations in soil and impacts earthworms and cultivated plants. J Environ Sci Heal Part A Toxic/Hazardous Subst Environ Eng 54:1441-1447. https://doi.org/10.1080/10934529.2019.1655368

27. Parente CET, Sierra J, Martí E (2018) Ecotoxicity and biodegradability of oxytetracycline and ciprofloxacin on terrestrial and aquatic media. Orbital 10:262-271. https://doi.org/10.17807/orbital.v10i4.1063

28. Litskas VD, Karamanlis XN, Prousali SP, Koveos DS (2018) Effects of the Antibiotic Amoxicillin on Key Species of the Terrestrial Environment. Bull Environ Contam Toxicol 100:509-515. 
https://doi.org/10.1007/s00128-018-2302-z

29. Liu F, Ying GG, Tao R et al (2009) Effects of six selected antibiotics on plant growth and soil microbial and enzymatic activities. Environ Pollut 157:1636-1642. https://doi.org/10.1016/j.envpol.2008.12.021

30. Liu F, Ying GG, Yang LH, Zhou QX (2009) Terrestrial ecotoxicological effects of the antimicrobial agent triclosan. Ecotoxicol Environ Saf 72:86-92. https://doi.org/10.1016/j.ecoenv.2008.06.009

31. Migliore L, Brambilla G, Cozzolino S, Gaudio L (1995) Effect on plants of sulphadimethoxine used in intensive farming (Panicum miliaceum, Pisum sativum and Zea mays). Agric Ecosyst Environ 52:103-110. https://doi.org/10.1016/0167-8809(94)00549-T

32. Richter E, Berkner S, Ebert I et al (2016) Results of extended plant tests using more realistic exposure scenarios for improving environmental risk assessment of veterinary pharmaceuticals. Environ Sci Eur 28:1-17. https://doi.org/10.1186/s12302-016-0089-2

33. Singer AC, Shaw H, Rhodes V, Hart A (2016) Review of antimicrobial resistance in the environment and its relevance to environmental regulators. Front Microbiol 7:1728

34. Grenni P, Ancona V, Barra Caracciolo A (2018) Ecological effects of antibiotics on natural ecosystems: A review. Microchem J 136:25-39. https://doi.org/10.1016/j.microc.2017.02.006

35. de la Torre A, Iglesias I, Carballo $M$ et al (2012) An approach for mapping the vulnerability of European Union soils to antibiotic contamination. Sci Total Environ 414:672-679. https://doi.org/10.1016/j.scitotenv.2011.10.032

36. Williams-Nguyen J, Sallach JB, Bartelt-Hunt S et al (2016) Antibiotics and Antibiotic Resistance in Agroecosystems: State of the Science. J Environ Qual 45:394-406. https://doi.org/10.2134/JEQ2015.07.0336

37. Bártíková H, Podlipná R, Skálová L (2016) Veterinary drugs in the environment and their toxicity to plants. Chemosphere 144:2290-2301

38. Minden V, Deloy A, Volkert AM et al (2017) Antibiotics impact plant traits, even at small concentrations. AoB Plants 9. https://doi.org/10.1093/aobpla/plx010

39. Reberg-Horton SC, Mueller JP, Mellage SJ et al (2011) Influence of field margin type on weed species richness and abundance in conventional crop fields. Renew Agric Food Syst 26:127-136. https://doi.org/10.1017/S1742170510000451

40. Directive 92/18/EC Commission Directive 92/18/EEC of 20 March 1992 modifying the Annex to Council Directive 81/852/EEC on the approximation of the laws of Member States relating to analytical, pharmacotoxicological and clinical standards and protocols in respect of the text

41. CVMP (2017) Committee for Medicinal Products for Veterinary Use. Guideline on the conduct of bioequivalence studies for veterinary medicinal products. London, UK

42. de la Torre A, Haro A, Carballo M et al (2018) Challenges in Risk Assessment and Management of Veterinary Medicines for Plants: Gaps and Reflections for an Updated Approach. Biomed J Sci Tech Res 5. https://doi.org/10.26717/bjstr.2018.05.001198 
43. Küster A, Adler N (2014) Pharmaceuticals in the environment: Scientific evidence of risks and its regulation. Philos Trans R Soc B Biol Sci 369. https://doi.org/10.1098/rstb.2013.0587

44. Eurostat (2020) Agriculture, forestry and fishery statistics: 2020 edition. Louxembourg

45. Olson DM, Dinerstein E, Wikramanayake ED et al (2001) Terrestrial Ecoregions of the World: A New Map of Life on Earth: A new global map of terrestrial ecoregions provides an innovative tool for conserving biodiversity. Bioscience 51:933-938. https://doi.org/10.1641/00063568(2001)051[0933:TEOTWA]2.0.C0;2

46. Martínez-Fernández J, Ruiz-Benito P, Zavala MA (2015) Recent land cover changes in Spain across biogeographical regions and protection levels: Implications for conservation policies. Land use policy 44:62-75. https://doi.org/10.1016/j.landusepol.2014.11.021

47. Jung M, Arnell A, de Lamo X et al (2020) Areas of global importance for terrestrial biodiversity, carbon, and water. bioRxiv 27. https://doi.org/10.1101/2020.04.16.021444. 2020.04.16.021444

48. Tieskens KF, Schulp CJE, Levers C et al (2017) Characterizing European cultural landscapes: Accounting for structure, management intensity and value of agricultural and forest landscapes. Land use policy 62:29-39. https://doi.org/10.1016/j.landusepol.2016.12.001

49. Eurostat (2020) Agricultural production - livestock and meat - Statistics Explained. https://ec.europa.eu/eurostat/statistics-explained/index.php?title=Agricultural_production__livestock_and_meat\&oldid=427096\#Poultry. Accessed 17 Jun 2021

50. Huyghe C, De Vliegher A, Van Gils B, Peeters A (2014) Grasslands and Herbivore Production in Europe and Effects of Common Policies

51. San Miguel A, Roig S, Perea R (2016) The pastures of Spain. Pastos Rev la Soc Española para el Estud los Pastos 46:6-39

52. ESRI (2011) ArcGIS Desktop: Release 10

53. R Core Team (2020) R: A Language and. Environment for Statistical Computing

54. European Medicines Agency (2016) Guideline on environmental impact assessment for veterinary medicinal products in support of the VICH guidelines GL6 and GL38

55. Augère-Granier M-L (2019) The EU poultry meat and egg sector. Main features, challenges and prospects. Brussels

56. Silverman BW (1986) Density Estimation for Statistics and Data Analysis. Chapman and Hall, New York, USA

57. MAPA (2004) Real Decreto 479/2004, de 26 de marzo, por el que se establece y regula el Registro general de explotaciones ganaderas. BOE (Official State Gazette), Spain

58. Loyon L (2018) Overview of Animal Manure Management for Beef, Pig, and Poultry Farms in France. Front Sustain Food Syst 2:36. https://doi.org/10.3389/fsufs.2018.00036

59. Smith KA, Brewer AJ, Crabb J, Dauven A (2001) A survey of the production and use of animal manures in England and Wales. II. Poultry manure. Soil Use Manag 17:48-56.

https://doi.org/10.1111/j.1475-2743.2001.tb00007.x

Page 27/33 
60. Smith KA, Brewer AJ, Crabb J, Dauven A (2001) A survey of the production and use of animal manures in England and Wales. III. Cattle manures. Soil Use Manag 17:77-87. https://doi.org/10.1111/j.1475-2743.2001.tb00012.x

61. CNIG (2014) SIOSE: Information System about Land Cover in Spain

62. García-Álvarez D, García Álvarez D (2018) The Influence of Scale in LULC Modeling. A Comparison Between Two Different LULC Maps (SIOSE and CORINE). In: Camacho Olmedo M, Paegelow M, Mas J, Escobar F (eds) Geomatic Approaches for Modeling Land Change Scenarioss. Lecture Notes in Geoinformation and Cartography. Springer International Publishing, pp 187-213

63. Piñeiro J, Castro J, Blázquez R (2010) Abonado de los cultivos forrajeros. Guía práctica de la fertilización racional de los cultivos en Espña. Ministerio de Medio Ambiente y Medio Rural y Marino, pp 173-180Ministerio de Medio Ambiente y Medio Rural y Marino

64. MAGRAMA (2014) Real Decreto 1077/2014 de 19 de diciembre, por el que se regula el sistema de información geográfica de parcelas agrícolas. BOE (Official State Gazette), Spain

65. Ferrer C, San Miguel A, Olea L (2001) Nomenclátor básico de pastos en España. Pastos Rev la Soc Española para el Estud los Pastos 31:7-44

66. Lindstrom MJ, Bates DM (1988) Newton-Raphson and EM algorithms for linear mixed-effects models for repeated-measures data. J Am Stat Assoc 83:1014-1022.

https://doi.org/10.1080/01621459.1988.10478693

67. Lenth R, Singmann H, Love J et al (2019)Package 'emmeans'

68. GBIF (2014) GBIF data portal. Global Biodiversity Inf

69. USDA-ARS (2014) National Genetic Resources Program Germplasm Resources Information Network (GRIN). National Germplasm Resour. Laboratory, Beltsville, MD. https://npgsweb.ars-grin.gov/ gringlobal/taxon/taxonomysearch.aspx

70. Iriondo JM, Albert MJ, Giménez L et al (2009) Poblaciones en peligro: Viabilidad demográfica de la Flora Vascular Amenazada de España. Dirección General de Medio Natural y Política Forestal. Ministerio de Medio Ambiente, y Medio Rural y Marino), Madrid, Spain

71. García RM, Parra-Quijano M, Iriondo JM (2017) Identification of ecogeographical gaps in the Spanish Aegilops collections with potential tolerance to drought and salinity. PeerJ 2017:e3494. https://doi.org/10.7717/peerj.3494

72. Simpson EH (1949) Measurement of diversity. Nature 163:688. https://doi.org/10.1038/163688a0

73. Pielou EC (1966) The measurement of diversity in different types of biological collections. J Theor Biol 13:131-144. https://doi.org/10.1016/0022-5193(66)90013-0

74. Sundseth K (2008) Natura 2000: Protecting Europe's biodiversity. Oxford, United Kingdom

75. Spanish Ministry of Environment (2020) Reservas de la Biosfera (MaB). In: Banco Datos la Nat. https://www.miteco.gob.es/es/biodiversidad/servicios/banco-datos-naturaleza/informaciondisponible/mab.aspx. Accessed 18 Oct 2020

76. MAPA (2008) Autochthonous Livestock in Spain. MAGRAMA 
77. Paül V, Tort J, Lois González RC (2018) Roser Majoral's (1942-2005) Geographies: From the Pyrenees to the Himalayas - A Life Devoted to Internationalising Spanish Geography. In: Paül V, Lois González RC, Trillo-Santamaría J-M, Haslam McKenzie F (eds) Infinite Rural Systems in a Finite Planet: Bridging Gaps towards Sustainability. Universidad de Santiago de Compostela, Santiago de Compostela, Spain., pp 543-570

78. Santos-Martín F, Zorrilla-Miras P, García-Llorente M et al (2019) Identifying win-win situations in agricultural landscapes: an integrated ecosystem services assessment for Spain. Landsc Ecol 34:1789-1805. https://doi.org/10.1007/s10980-019-00852-5

79. Segrelles JA (1993) La ganadería avícola y porcina en España: del aprovechamiento tradicional al industrializado

80. Parente G (2011) Grazing systems and biodiversity in Mediterranean areas: Spain, Italy and Greece. Grass Forage Sci 66:606-606. https://doi.org/10.1111/j.1365-2494.2011.00820.x

81. MAPA (2021) Producciones agrícolas en España: Cultivos herbáceos e industriales. https://www.mapa.gob.es/es/agricultura/temas/producciones-agricolas/cultivos-herbaceos/

82. European Commission (2019) EU Agricultural outlook for the agricultural markets and income 20172030

83. Martínez A, Pedrol N, Piñero J (2005) Cultivares de Haboncillo (Vicia faba L.) y Triticale (x Triticosecale Wittm.) para producción de forraje invernal en zonas húmedas con mezclas cereal leguminosa. (ed) XLV Reunión Científica de la SEEP. SERIDA, pp 673-679UN FAO of the

84. Jiang X, Chen Z, Dharmasena M (2015) The role of animal manure in the contamination of fresh food. In: Advances in Microbial Food Safety. Woodhead Publishing, pp 312-350

85. Kumar K, Gupta SC, Baidoo SK et al (2005) Antibiotic Uptake by Plants from Soil Fertilized with Animal Manure. J Environ Qual 34:2082-2085. https://doi.org/10.2134/jeq2005.0026

86. Delgado MM, Martin JV, Imperial RM, De et al (2010) Phytotoxicity of uncomposted and composted poultry manure. African J Plant Sci 4:151-159. https://doi.org/10.5897/AJPS.9000191

87. Esperón F, Albero B, Ugarte-Ruíz M et al (2020) Assessing the benefits of composting poultry manure in reducing antimicrobial residues, pathogenic bacteria, and antimicrobial resistance genes: a fieldscale study. Environ Sci Pollut Res 27:27738-27749. https://doi.org/10.1007/s11356-020-09097-1

88. Farooq MA, Ali B, Gill RA et al (2016) Breeding Oil Crops for Sustainable Production: Heavy Metal Tolerance. In: Breeding Oilseed Crops for Sustainable Production: Opportunities and Constraints. Academic Press, pp 19-31

89. MAPA (2020) Anuario de Estadística. MAPA, Madrid, Spain

90. European Commission (2021) Plants and plant products. https://ec.europa.eu/info/food-farmingfisheries/plants-and-plant-products_en. Accessed 16 Sep 2021

91. Řezbová H, Belová A, Škubna O (2013) Sugar beet production in the european union and their future trends. Agris On-line Pap Econ Informatics 5:165-178

92. EMA (2011) Reflection paper on testing strategy and risk assessment for plants 
93. Carballo M, Rodríguez A, de la Torre A (2021) Phytotoxic Effects of Antibiotics on Terrestrial Crop Plants and Wild Plants: A Systematic Review. Springer

94. Myers N, Mittermeler RA, Mittermeler CG et al (2000) Biodiversity hotspots for conservation priorities. Nature 403:853-858. https://doi.org/10.1038/35002501

95. Schröter D, Cramer W, Leemans R et al (2005) Ecology: Ecosystem service supply and vulnerability to global change in Europe. Science (80-) 310:1333-1337. https://doi.org/10.1126/SCIENCE.1115233

96. Roche MJ, McCowan Cl, Kelly JC (2012) Suspected poisoning of cattle by scarlet pimpernel (Lysimachia arvensis L.). Aust Vet J 90:269-271. https://doi.org/10.1111/j.1751-0813.2012.00930.x

97. Marshall EJP, Brown VK, Boatman ND et al (2003) The role of weeds in supporting biological diversity within crop fields. Weed Res 43:77-89

98. Adeux G, Vieren E, Carlesi S et al (2019) Mitigating crop yield losses through weed diversity. Nat Sustain 2:1018-1026. https://doi.org/10.1038/s41893-019-0415-y

99. Cirujeda A, Pardo G, Marí Al et al (2019) The structural classification of field boundaries in Mediterranean arable cropping systems allows the prediction of weed abundances in the boundary and in the adjacent crop. Weed Res 59:300-311. https://doi.org/10.1111/wre.12366

100. Cirujeda A, Aibar J, Zaragoza C (2011) Remarkable changes of weed species in Spanish cereal fields from 1976 to 2007. Agron Sustain Dev 31:675-688

101. Storkey J (2006) A functional group approach to the management of UK arable weeds to support biological diversity. Weed Res 46:513-522. https://doi.org/10.1111/j.1365-3180.2006.00528.x

102. Pallavicini Y, Bastida F, Hernández-Plaza E et al (2020) Local factors rather than the landscape context explain species richness and functional trait diversity and responses of plant assemblages of mediterranean cereal field margins. Plants 9:1-24. https://doi.org/10.3390/plants9060778

103. Rubio Teso ML, Torres Lamas E, Parra-Quijano M et al (2018) National inventory and prioritization of crop wild relatives in Spain. Genet Resour Crop Evol 65:1237-1253. https://doi.org/10.1007/s10722018-0610-0

\section{Figures}




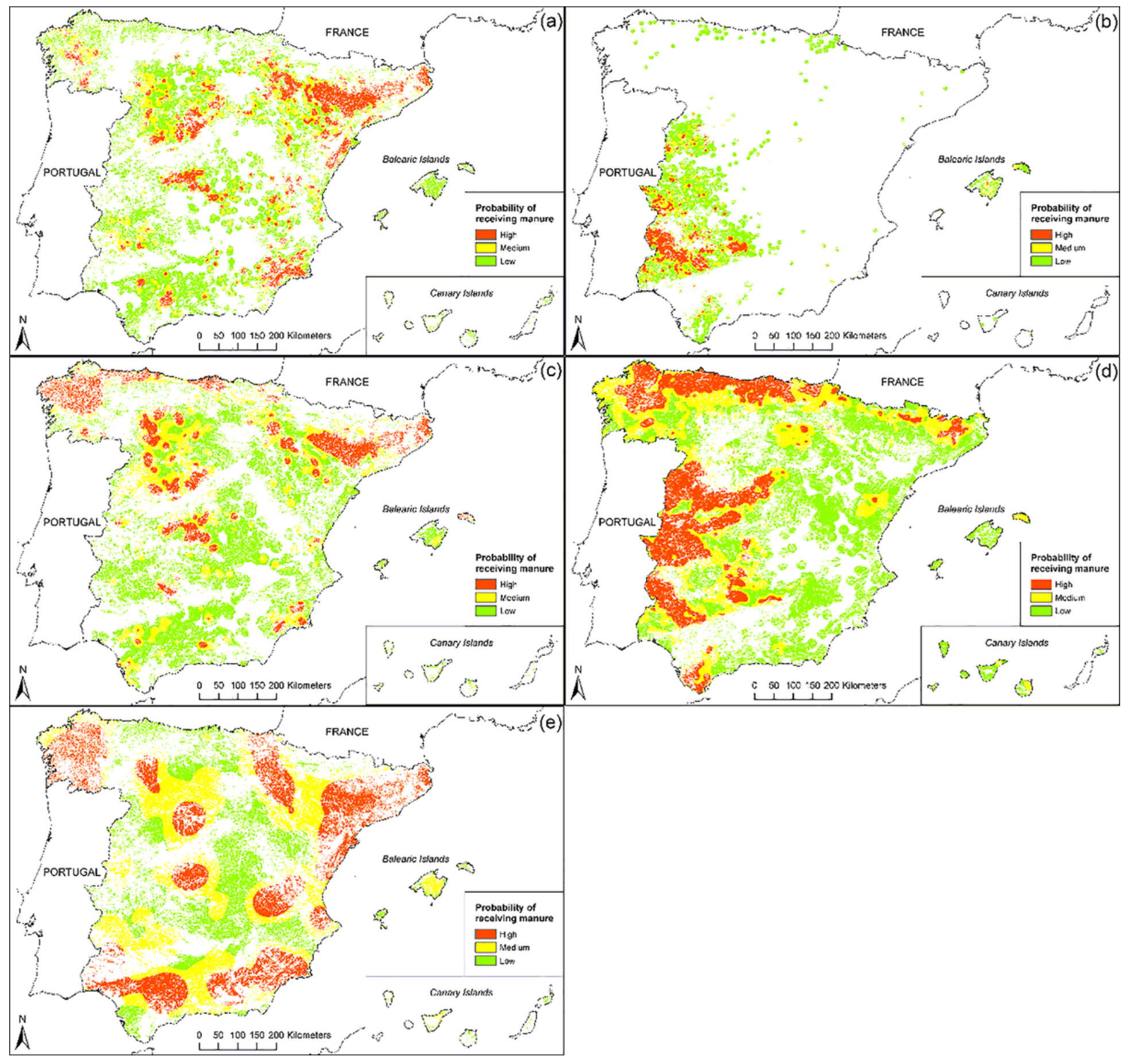

Figure 1

Probability of receiving manure from: (a) pig in agricultural scenarios; (b) pig in pasture scenarios; (c) cattle in agricultural scenarios; (d) cattle in pasture scenarios; (e) chicken in agricultural scenarios. 


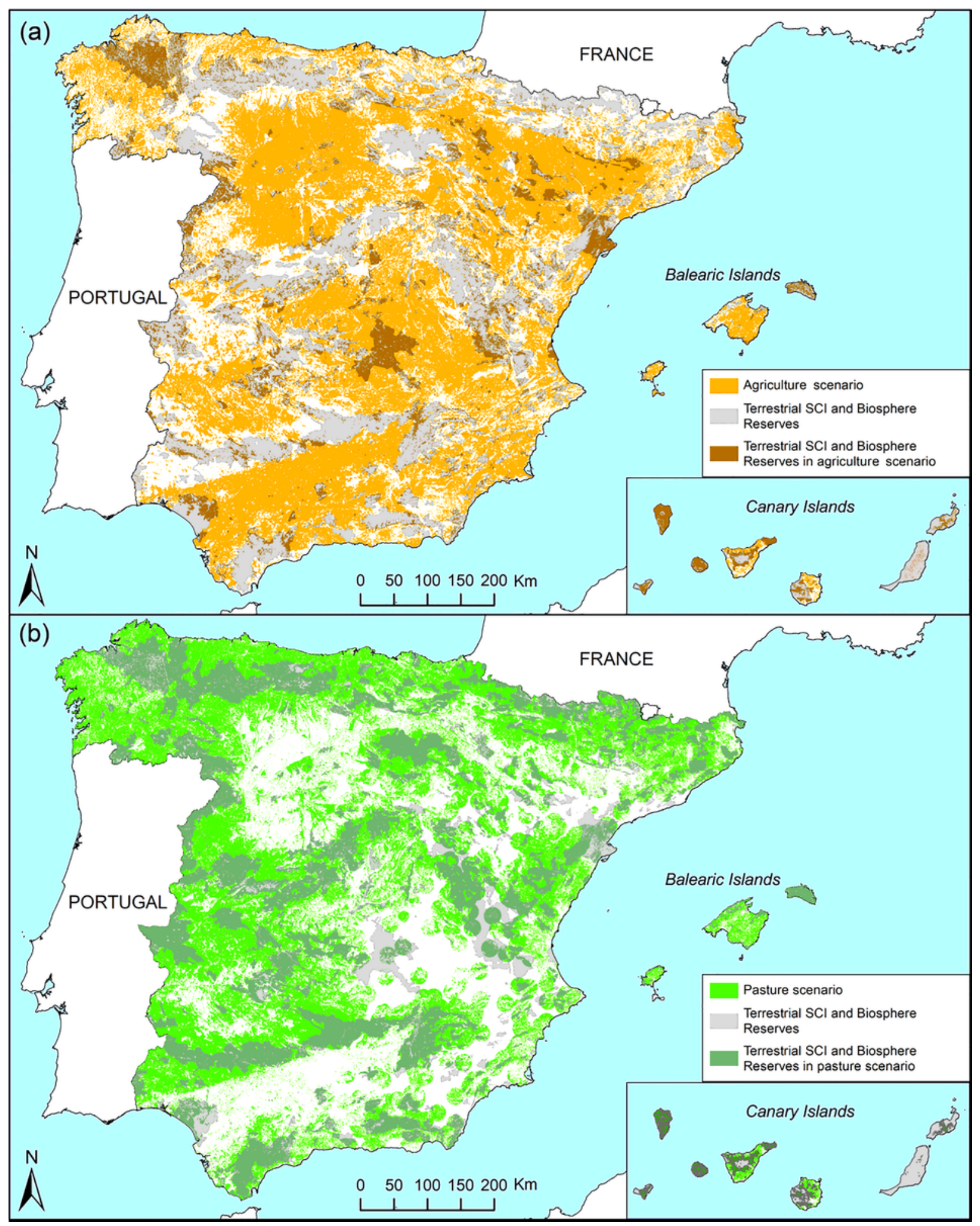

Figure 2

Overlap of the Sites of Community Importance (SCl) and Biosphere Reserves with agricultural (a) and pasture scenarios (b). Dark coloured areas correspond to areas of agricultural (orange) and pasture (green) scenarios, respectively, located inside a SCl or a Biosphere Reserve.

\section{Supplementary Files}


This is a list of supplementary files associated with this preprint. Click to download.

- AppendixA28102021.docx 